OmniAkuatika, 11(2): 41-49, 2015
ISSN: 1858-3873 print / 2476-9347 online
Research Article

\title{
AKTIVITAS ANTIMITOTIK DARI EKSTRAK KARANG LUNAK GENUS SINULARIA
}

\author{
Wendy Alexander Tanod ${ }^{1}$, Remy E. P. Mangindaan ${ }^{2}$ dan Magie Kapojos ${ }^{2}$ \\ ${ }^{1}$ Sekolah Tinggi Perikanan dan Kelautan (STPL) Palu \\ Jalan Soekarno Hatta KM.6 (Kampus Madani) Palu Sulawesi Tengah \\ ${ }^{2}$ Fakultas Perikanan dan IImu Kelautan (FPIK) Universitas Sam Ratulangi Manado \\ Jalan Kampus UNSRAT Kelurahan Bahu Manado Sulawesi Utara
}

${ }^{*}$ Corresponding authors : wendytanod@yahoo.com

\begin{abstract}
Soft coral genus Sinularia be a sources of terpenoid compounds that show efficacy in vitro cytotoxic test using cancer cell lines. The study looked at the morphological changes that occur in fungal mycelial growth of Pyricularia oryzae, such as curling effect indicating antimitotic activity. Four extracts of soft coral genus Sinularia have been examination and this is an primary test to obtain information about the soft coral genus Sinularia that used as sources of compound antimitotic. This research was conducted in several stages, ie extraction of bioactive substances, $P$. oryzae fungal culture test, and biological testing antimitotic activity with a qualitative assessment methods. From the examination the Sinularia 3 ethyl acetate fraction show the strongest antimitotic activity (to concentration $1,5 \mu \mathrm{g} / \mathrm{ml}$ ). Ethyl acetate fraction was purified using column chromatography. From the examination show that fraction of ethyl acetate 1 is the best fraction because still show curling effect on concentration 0,7 $\mu \mathrm{g} / \mathrm{ml}$.
\end{abstract}

Keywords : Antimitotic, Soft Coral, Sinularia, microtubule, Pyricularia oryzae

\section{PENDAHULUAN}

Daerah laut tropis termasuk Indonesia memiliki spesies-spesies organisme laut yang beraneka ragam dan berpotensi sebagai sumber senyawa bioaktif yang baru. Berdasarkan telaah pustaka organisme laut seperti karang lunak diketahui merupakan sumber dari berbagai variasi metabolit sekunder, terutama golongan senyawa terpenoid. Senyawa-senyawa turunan terpenoid ini menunjukkan efek sitotoksik pada beberapa galur sel. Menurut Andersen et al. (2004), sebagian besar produk alami yang memiliki aktivitas antimitotik awalnya terisolasi karena menunjukkan keampuhan sitotoksisitas secara in vitro dalam pengujian menggunakan galur sel kanker.

Senyawa antimitotik mempunyai kemampuan mengikat tubulin dan menghambat polimerisasi tubulin menjadi mikrotubulus sehingga terjadi penghancuran mikrotubulus dan menyebabkan mitosis sel kanker terhenti dan akan diikuti oleh kematian sel (apoptosis). Oleh karena itu, antimitotik juga dapat disebut antimikrotubulus. Mikrotubulus berbentuk gelendong dalam pembelahan. Dalam sel normal, mikrotubulus terbentuk ketika sel mulai membagi selama mitosis. Gascoigne dan
Taylor (2009), agen antimitotik tidak mempengaruhi pembelahan sel sehat. Cara kerja agen antimitotik mempengaruhi motor protein (kinesin dan dynein) yang diperlukan untuk pemisahan poros kutub selama pembelahan mitosis. Oleh karena itu, senyawa antimitotik bekerja lebih aman pada pengobatan penyakit kanker.

Pada penelitian ini, digunakan konidia dan miselia jamur Pyricularia oryzae. Perubahan-perubahan morfologi yang terjadi pada miselia jamur $P$. oryzae ditentukan untuk menemukan adanya aktivitas antimitotik. Penelitian ini merupakan pengujian awal dalam mendapatkan informasi mengenai karang lunak genus Sinularia yang berpotensi sebagai sumber senyawa antimitotik. Hal ini merupakan langkah awal untuk menemukan senyawasenyawa antimitotik sebagai bahan baku obat kanker yang lebih aman digunakan. Penelitian ini bertujuan menemukan aktivitas antimitotik dari karang lunak genus Sinularia dan menentukan fraksi unggul yang menunjukkan aktivitas antimitotik.

\section{MATERIAL DAN METODE}

Ekstraksi sampel dan pengujian aktivitas antimitotik dilakukan di Laboratorium Kimia 
Bahan Hayati Laut FPIK UNSRAT. Ekstrak hasil partisi sampel karang lunak diperoleh dari stok laboratorium kimia bahan hayati laut yang disimpan dalam freezer dan telah dipartisi dengan pelarut etil asetat, n-heksan dan nbutanol. Sampel karang lunak yang digunakan diambil dari perairan pantai Malalayang Kota Manado. Pengambilan dengan cara snorkling dan diekstraksi secara kasar menggunakan etanol dengan 3 kali penyaringan dan dipartisi bertingkat berdasarkan kepolaran (Rumbarar, 2008). Fraksi hasil partisi yang menunjukkan aktivitas antimitotik terkuat, dimurnikan melalui kromatografi kolom dan selanjutnya diinjeksi ke Kromatografi Cair Kinerja Tinggi (KCKT) yang dilakukan di Universitas Tohoku Pharmaceutical Jepang.

\section{Ekstraksi Substansi Bioaktif}

Pada penelitian ini menggunakan tiga fraksi hasil partisi yang telah dilakukan sebelumnya oleh Rumbarar (2008). Hasil pengujian awal menunjukkan bahwa fraksi etil asetat menunjukkan aktivitas antimitotik yang paling kuat. Berdasarkan hal itu, maka fraksi etil asetat hasil partisi dari keempat jenis karang lunak diuji aktivitas biologisnya terhadap pertumbuhan miselia jamur uji. Fraksi hasil partisi dari jenis karang lunak yang menunjukkan aktivitas terkuat dimurnikan melalui kromatografi kolom dengan memanfaatkan gravitasi. Kolom kromatografi yang digunakan berukuran panjang $55 \mathrm{~cm}$ dan diameter $1,5 \mathrm{~cm}$ dengan fase diam Silica gel 60 (Si-60) dan fase gerak kloroform $\left(\mathrm{CHCl}_{3}\right)$ : metanol (MeOH). Setelah dialiri, sebanyak 2,19 $\mathrm{g}$ fraksi etil asetat dilewatkan dan dielusi dengan $200 \mathrm{ml} \mathrm{CHCl} 3$ : $\mathrm{MeOH}$ (100:0). Selanjutnya, dialiri $200 \mathrm{ml} \mathrm{CHCl}_{3}: \mathrm{MeOH}$ dengan perbandingan $90: 10,80: 20,70: 30,50$ : $50,30: 70,20: 80,10: 90$ dan $0: 100$. Tiap $10 \mathrm{ml}$ eluen yang keluar dari kolom kromatografi ditampung dan diuapkan dengan evaporator. Kemudian, nilai absorbansinya diukur dengan spektrofotometer UV-Vis Thermo Electron panjang gelombang $280 \mathrm{~nm}$. Pengukuran pada panjang gelombang $280 \mathrm{~nm}$ berdasarkan bahwa senyawa golongan terpenoid yang umum terdapat pada karang lunak menyerap sinar UV-vis pada panjang gelombang $245 \mathrm{~nm}-416 \mathrm{~nm}$. Tiap puncak yang diperoleh dari hasil pengukuran spektrofotometer UV-vis Thermo Electron, diuji aktivitas biologisnya terhadap konidia dan miselia jamur Pyricularia oryzae. Fraksi hasil kromatografi kolom diinjeksi ke alat KCKT. Tipe dan jenis KCKT yang digunakan ialah Hitachi RP-HPLC dengan kolom : PEGASIL ODS (5 $\mu \mathrm{m}, 10 \mathrm{~mm} \times 250 \mathrm{~mm}$,Senshu Scientific Co., Ltd., Japan).

\section{Kultur Jamur Uji $P$. oryzae}

P. oryzae dikultur menggunakan media PDA (Potato Dextrose Agar) selama 7 hari pada suhu $27^{\circ} \mathrm{C}$. Untuk mendapatkan suspensi konidia, $P$. oryzae ditumbuhkan pada media miring YSA dengan komposisi yeast extract 0,2 $\mathrm{g}$, soluble starch $1 \mathrm{~g}$ dan agar $1,5 \mathrm{~g}$ dalam 100 $\mathrm{ml}$ air steril. Selanjutnya, jamur uji diinokulasikan ke media miring steril dan diinkubasi pada suhu $27^{\circ} \mathrm{C}$ selama $12-14$ hari. Isolat jamur diinkubasi dengan kondisi 12 jam terang dan 12 jam gelap.

\section{Prosedur Pengujian Biologis Aktivitas Antimitotik}

Pengujian aktivitas antimitotik menggunakan metode yang digunakan oleh Kobayashi, et al (1996) yang telah dimodifikasi. Setelah jamur uji pada media miring diinkubasi selama 12-14 hari, konidia jamur disuspensikan ke dalam $5 \mathrm{ml}$ air steril melalui penyaringan. Filtrat yang diperoleh ditambahkan yeast extract $1,3 \mathrm{~g}$, soluble starch $0,8 \mathrm{~g}$, dan air steril $5 \mathrm{ml}$. Jumlah suspensi konidia yang digunakan pada tiap pengujian berkisar antara $2 \times 10^{3}$ sampai $4 \times 10^{4} \mathrm{konidia} / \mathrm{ml}$.

Pengujian aktivitas antimitotik dilakukan dengan cara memasukkan $50 \mu \mathrm{L}$ air steril kedalam sumur A-H dari mikrotiterplate. Setelah itu, $50 \mu \mathrm{L}$ ekstrak uji konsentrasi 200 $\mu \mathrm{g} / \mathrm{ml}$ yang dilarutkan dengan DMSO ditambahkan pada sumur A. Suspensi ini dicampur rata kemudian diambil $50 \mu \mathrm{L}$ dan dimasukkan ke dalam sumur B. Prosedur tersebut diulangi sampai pada sumur $\mathrm{H}$ sehingga terbentuk suatu seri pengenceran 100 $\mu \mathrm{g} / \mathrm{ml} ; 50 \mu \mathrm{g} / \mathrm{ml} ; 25 \mu \mathrm{g} / \mathrm{ml} ; 12,5 \mu \mathrm{g} / \mathrm{ml} ; 6,25$ $\mu \mathrm{g} / \mathrm{ml} ; 3,1 \mu \mathrm{g} / \mathrm{ml} ; 1,5 \mu \mathrm{g} / \mathrm{ml}$ dan $0,7 \mu \mathrm{g} / \mathrm{ml}$. Selanjutnya, $50 \mu \mathrm{L}$ suspensi konidia jamur $P$. oryzae dimasukkan ke semua sumur pengujian. Mikrotiterplate diinkubasi pada suhu $27{ }^{\circ} \mathrm{C}$ selama 14 jam. Pengamatan dilakukan menggunakan mikroskop binokuler Olympus pada pembesaran 400x dan pertumbuhan jamur uji dibandingkan dengan kontrol negatif dan positif. Air steril digunakan sebagai kontrol negatif dan rhizoxin digunakan sebagai kontrol positif. Prosedurnya dapat dilihat pada Gambar 1.

\section{Pengujian Kontrol Positif dan Negatif}

Pada penelitian ini, pengujian aktivitas antimitotik menggunakan rhizoxin sebagai kontrol positif, sedangkah air steril, metanol dan 
DMSO (Dimethyl sulfoxide) sebagai kontrol negatif. Metanol dan DMSO digunakan untuk melarutkan esktrak kering. Pengujian menggunakan pelarut metanol dan DMSO dengan konsentrasi $70 \%, 35 \%, 17,5 \%, 8,7 \%$, $4,3 \%, 2,1 \%, 1 \%$ dan $0,5 \%$ pada sumur $A$ sampai $H$. Konsentrasi pelarut yang dipilih, yaitu pelarut yang tidak memberikan efek terhadap pertumbuhan jamur uji $P$. Oryzae.

Air steril digunakan sebagai kontrol bahwa pertumbuhan jamur tetap normal pada kondisi tanpa perlakuan dan pemberian ekstrak. Rhizoxin sebagai kontrol positif menunjukkan efek pengeritingan miselia $P$. oryzae dari konsentrasi $50 \mu \mathrm{g} / \mathrm{ml}$ sampai konsentrasi $0,3 \mu \mathrm{g} / \mathrm{ml}$.

\section{Pengujian Ekstrak Karang Lunak}

Pada penelitian ini, menggunakan ekstrak yang telah dipartisi secara bertingkat dengan pelarut etil asetat, heksan dan butanol. Hasil penelitian Rumbarar (2008) menunjukkan bahwa fraksi etil asetat dari keempat jenis karang lunak, merupakan kelompok fraksi yang paling baik menunjukkan aktivitas pengeritingan pada pertumbuhan jamur uji $P$. Oryzae. Oleh karena itu, penelitian ini menggunakan semua fraksi etil asetat keempat jenis kerang lunak untuk membuktikannya.
Pengujian tahap 1 menentukan jenis karang lunak yang menunjukkan aktivitas terkuat dengan menggunakan Fraksi etil asetat dari keempat jenis karang lunak. Setelah ditentukan jenis karang lunak yang paling aktif, selanjutnya pengujian tahap 2 menentukan fraksi hasil partisi yaitu etil asetat, heksan dan butanol dari satu jenis karang lunak yang paling aktif. Lalu dari hasil pengujian tahap 2 ditentukan, fraksi hasil partisi yang menunjukkan aktivitas terkuat akan dimurnikan dengan kromatografi kolom vertikal. Selanjutnya pengujian tahap 3 menggunakan fraksi hasil kromatografi kolom untuk menentukan fraksi yang terkuat.

\section{Penetapan Penilaian Kualitatif}

Penilaian kualitatif pertumbuhan miselia jamur $P$. oryzae, mengikuti panduan Kobayashi, et al (1996). Indeks dari pertumbuhan dan perkembangan konidia dan miselia dibagi ke dalam 3 kategori, yaitu indeks (+) menunjukkan efek pengeritingan dari miselia jamur uji, indeks $(x)$, menunjukkan miselia jamur uji tidak tumbuh dan indeks (-) berarti pertumbuhan normal miselia jamur uji. Aktivitas antimitotik ditunjukkan dengan miselia jamur $P$. oryzae yang mengeriting.

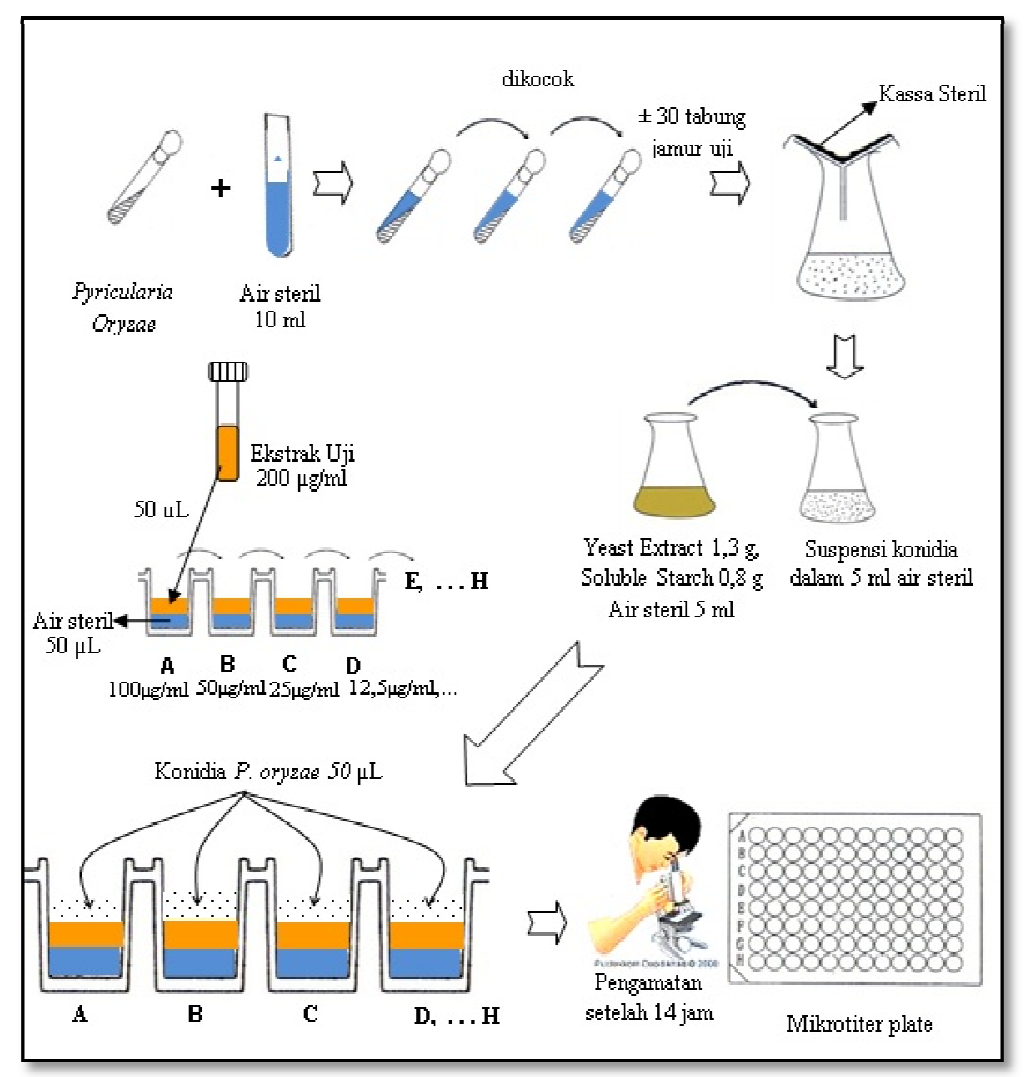

Gambar 1. Prosedur Kerja Pengujian Biologis Aktivitas Antimitotik 


\section{Kromatogram dari Fraksi Hasil Kromatografi Cair Kinerja Tinggi}

Fraksi etil asetat 1 , etil asetat 2 dan etil asetat 3 yang diperoleh dari proses kromatografi kolom kemudian diinjeksi ke kromatografi cair kinerja tinggi (KCKT) sebanyak $15 \mu$ dengan konsentrasi $1 \mathrm{mg} / \mathrm{ml}$ pada laju aliran $0,8 \mathrm{ml} / \mathrm{min}$ menggunakan eluen metanol $60 \%$. Setiap puncak yang terbentuk pada kromatogram menunjukkan adanya suatu senyawa dalam sampel. Pada panjang gelombang $220 \mathrm{~nm}$, kromatogram fraksi etil asetat 1 menunjukkan sebelas puncak yang diperkirakan terdapat sebelas senyawa pada fraksi etil asetat 1. Hasil kromatogram pada fraksi etil asetat 2 terdeteksi sepuluh puncak. Pada fraksi etil asetat 3 menunjukkan delapan puncak diperkirakan ada delapan senyawa yang terdeteksi.

\section{HASIL DAN PEMBAHASAN}

\section{Identifikasi Sampel Karang Lunak}

Berdasarkan bentuk koloni dan sklerit basal, keempat sampel karang lunak teridentifikasi masuk ke dalam genus Sinularia (Identifikasi sampel sampai genus oleh Dr. Lee Van Ofwegen dari Netherlands Centre for Biodiversity Naturalis). Sampel karang lunak diberi kode Sinularia 1, Sinularia 2, Sinularia 3 dan Sinularia 4. Foto dan ciri-ciri sampel karang lunak dapat dilihat pada Tabel 1.

\section{Pengujian Biologis Aktivitas Antimitotik}

\section{Aktivitas Antimitotik pada Kontrol Positif dan Negatif}

Pengujian efek konsentrasi pelarut dilakukan agar konsentrasi pelarut yang digunakan untuk melarutkan ekstrak tidak memberikan efek pada miselia jamur $P$. oryzae. Hasil pengujian menunjukkan konsentrasi metanol 35\% dan DMSO 4,3\% tidak menunjukkan efek pengeritingan terhadap miselia jamur $P$. oryzae. Rhizoxin sebagai kontrol positif dalam pengujian ini, menunjukkan efek pengeritingan pertumbuhan miselia jamur $P$. oryzae. Efek pengeritingan merupakan perubahan bentuk pertumbuhan miselia yang berlekuk. Adanya simbol (+) pada konsentrasi rendah menunjukkan ekstrak memiliki aktivitas antimitotik terkuat, karena pada konsentrasi rendah ekstrak masih menunjukkan adanya efek pengeritingan. Sullivan et al (1990), menyatakan rhizoxin merupakan agen antimitotik yang potensial dalam penghambatan pertumbuhan sel tumor. Gambar 2 menunjukkan efek kontrol positif dan negatif terhadap pertumbuhan miselia jamur $P$. oryzae.

Tabel 1. Foto dan ciri-ciri sampel karang lunak

\begin{tabular}{|c|c|c|}
\hline & ularia 1 & Sinularia 2 \\
\hline 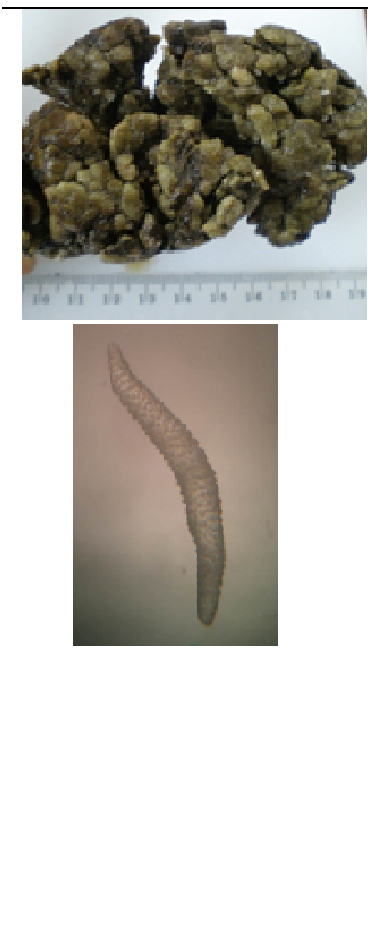 & 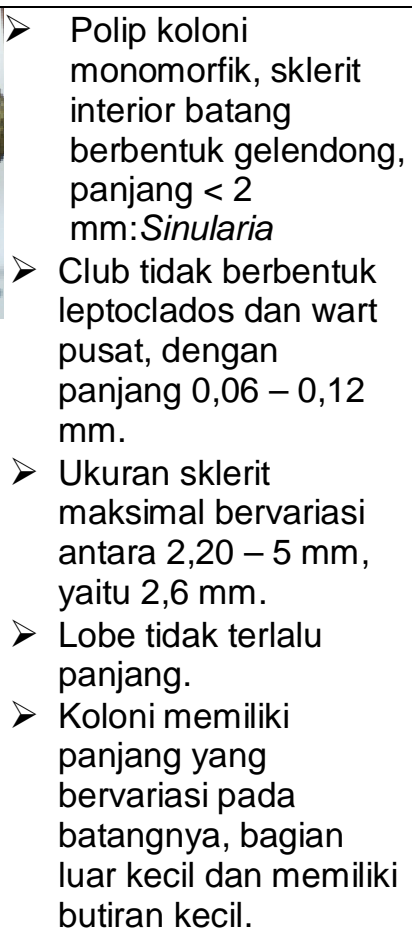 & $\begin{array}{l}>\text { Polip koloni } \\
\text { monomorfik, sklerit } \\
\text { interior batang } \\
\text { berbentuk gelendong, } \\
\text { panjang }<2 \\
\text { mm:Sinularia } \\
>\text { Club tidak berbentuk } \\
\text { leptoclados dan wart } \\
\text { pusat, dengan } \\
\text { panjang } 0,06-0,12 \\
\text { mm. } \\
>\text { Lobe dan Lobule } \\
\text { tegak lurus, seperti } \\
\text { jari. } \\
>\text { Sklerit interior tidak } \\
\text { bercabang, panjang < } \\
2,2 \mathrm{~mm}, \text { yaitu } 1,8 \mathrm{~mm} .\end{array}$ \\
\hline
\end{tabular}




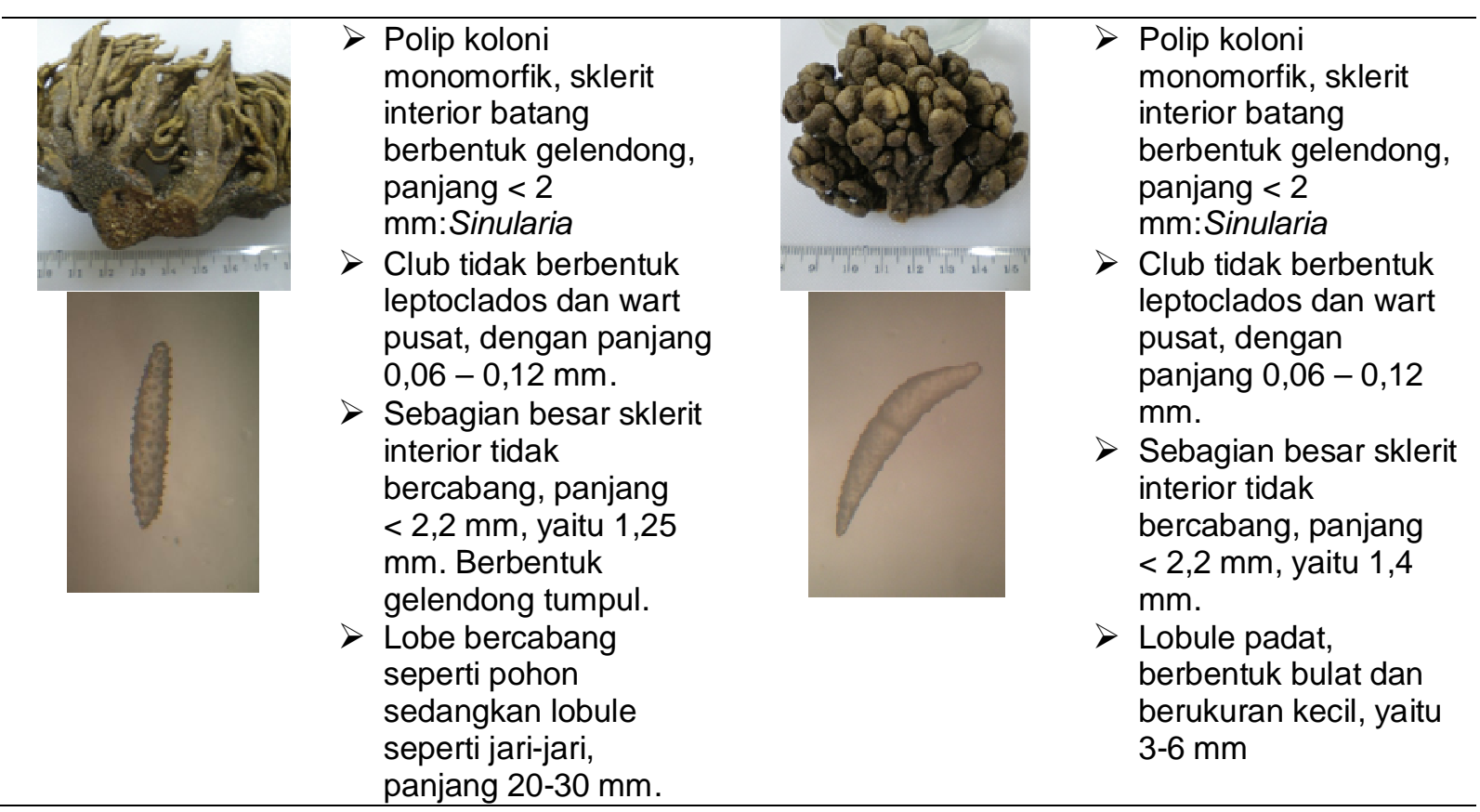

Diidentifikasi sampai tahap genus oleh Dr. Lee Van Ofwegen dari Netherlands Centre for Biodiversity Naturalis (Verseveldt, 1980).

Tabel 2. Hasil Pengujian Aktivitas Antimitotik menggunakan Fraksi Etil Asetat

\begin{tabular}{lcccccccc}
\hline \multirow{2}{*}{ Fraksi Etil Asetat } & \multicolumn{8}{c}{ Konsentrasi $(\boldsymbol{\mu g} / \mathbf{m l})$} \\
& $\mathbf{1 0 0}$ & $\mathbf{5 0}$ & $\mathbf{2 5}$ & $\mathbf{1 2 , 5}$ & $\mathbf{6 , 2}$ & $\mathbf{3 , 1}$ & $\mathbf{1 , 5}$ & $\mathbf{0 , 7}$ \\
\hline Sinularia 1 & + & + & + & + & + & - & - & - \\
Sinularia 2 & $\times$ & + & + & + & - & - & - & - \\
Sinularia 3 & $\times$ & + & + & + & + & + & + & - \\
Sinularia 4 & + & + & + & - & - & - & - & - \\
\hline
\end{tabular}

\section{Aktivitas Antimitotik pada Fraksi Hasil Partisi}

Keempat fraksi etil asetat hasil partisi karang lunak genus Sinularia, diuji terlebih dahulu terhadap kondia dan miselia jamur $P$. oryzae untuk mengetahui jenis karang lunak yang menunjukkan aktivitas antimitotik terkuat. Tabel 2 menunjukkan aktivitas antimitotik dari fraksi etil asetat hasil partisi karang lunak genus Sinularia.

Dari tabel 2 menunjukkan bahwa karang lunak Sinularia 3 menghasilkan efek yang signifikan pada pertumbuhan miselia jamur $P$. oryzae, sampai pada konsentrasi rendah $1,5 \mu \mathrm{g} / \mathrm{ml}$. Pengeritingan miselia jamur uji pada Sinularia 3 mirip dengan pengeritingan oleh flutamide. Flutamide adalah obat anti androgen oral nonsteroid terutama digunakan untuk mengobati kanker prostat yang mencegah perangsangan sel-sel kanker prostat untuk tumbuh (Chrousos, 2001). Dari survei literatur, senyawa-senyawa terpenoid yang didapat berasal dari fraksi hasil ekstraksi pelarut nonpolar seperti heksan dan semipolar seperti etil asetat dan kloroform. Oleh karena itu, fraksi yang mempunyai kandungan senyawa antimitotik pada Sinularia 3, diperkirakan termasuk dalam golongan terpenoid dan larut pada pelarut semipolar yaitu etil asetat. Hasil pengujian fraksi etil asetat dari empat jenis karang lunak dapat di lihat pada Gambar 3. 


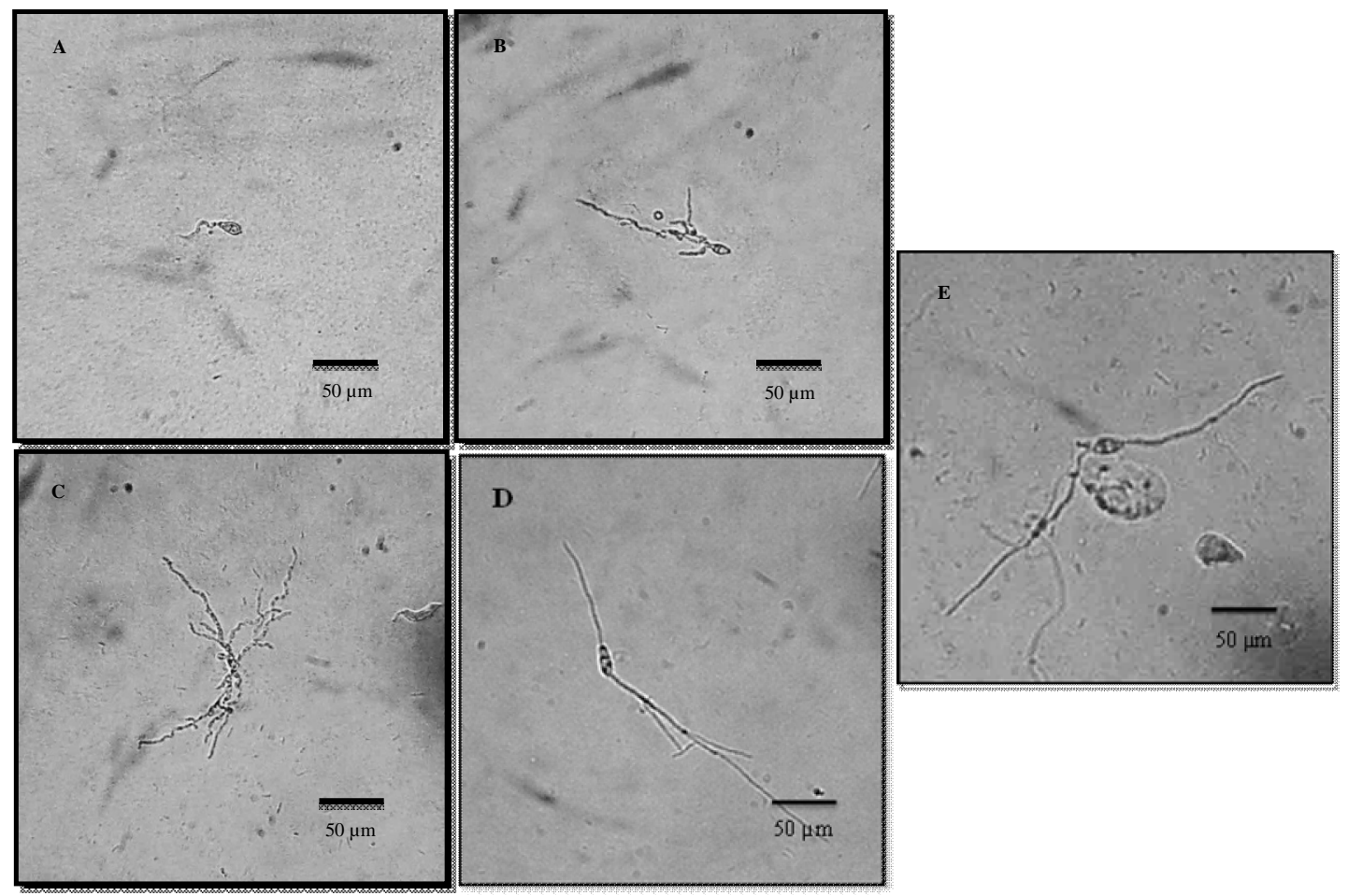

Keterangan : A.Rhizoxin $25 \mu \mathrm{g} / \mathrm{ml}$; B. Rhizoxin $6,2 \mu \mathrm{g} / \mathrm{ml}$; C. Rhizoxin 0,3 $\mu \mathrm{g} / \mathrm{ml}$; D. Air Steril; E. Metanol $35 \%$

Gambar 2. Efek Kontrol Positif dan Negatif Terhadap Pertumbuhan Miselia P. oryzae
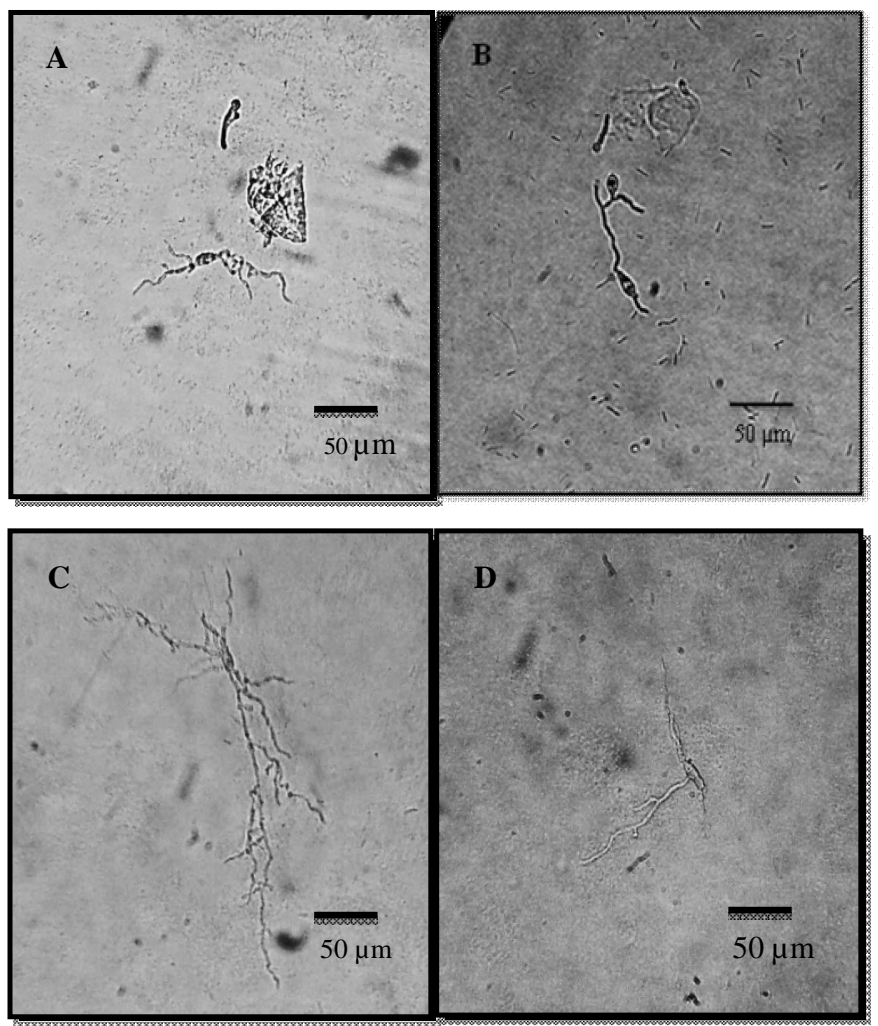

Keterangan : A. Sinularia $1 \quad 6,2 \mu \mathrm{g} / \mathrm{ml}$; B. Sinularia 2 12,5 $\mu \mathrm{g} / \mathrm{ml}$; C. Sinularia $3 \quad 1,5 \mu \mathrm{g} / \mathrm{ml}$; D. Sinularia $425 \mu \mathrm{g} / \mathrm{ml}$

Gambar 3. Efek Pengeritingan oleh Fraksi Etil Asetat Karang Lunak Genus Sinularia 


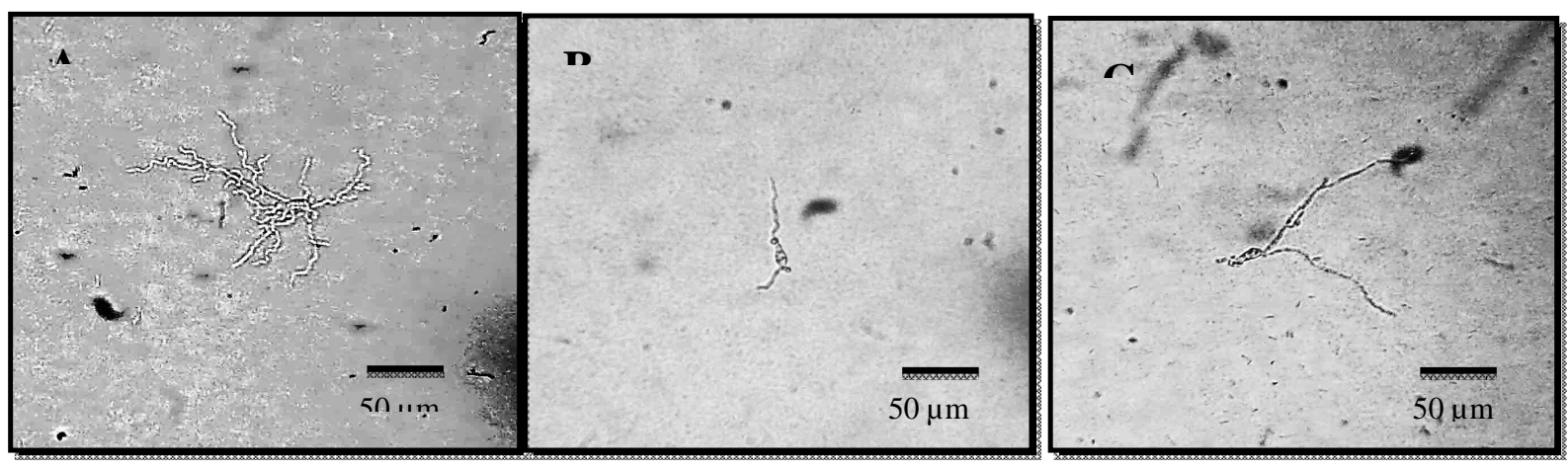

Keterangan : A. Fraksi Etil Asetat 1,5 $\mu \mathrm{g} / \mathrm{ml}$, B. Fraksi Heksan 12,5 $\mu \mathrm{g} / \mathrm{ml}$, C. Fraksi butanol $50 \mu \mathrm{g} / \mathrm{ml}$ Gambar 4. Efek Pengeritingan oleh Fraksi Hasil Partisi Sinularia 3

Selanjutnya, pengujian terhadap fraksi heksan, etil asetat dan butanol Sinularia 3 dilakukan untuk mengetahui fraksi yang menunjukkan aktivitas antimitotik terkuat dari ketiga fraksi untuk diteruskan ke kromatografi kolom. Dari hasil pengujian diketahui bahwa fraksi etil asetat Sinularia 3 menunjukkan efek pengeritingan sampai pada konsentrasi 1,5 $\mu \mathrm{g} / \mathrm{ml}$, sedangkan fraksi heksan dan fraksi butanol masing-masing menunjukkan efek pengeritingan hanya sampai pada konsentrasi $12,5 \mu \mathrm{g} / \mathrm{ml}$ dan $50 \mu \mathrm{g} / \mathrm{ml}$. Efek pengeritingan oleh fraksi hasil partisi Sinularia 3 dapat dilihat pada Gambar 4.

Aktivitas Antimitotik pada Fraksi Hasil Kromatografi Kolom Karang Lunak Sinularia 3
Diperoleh tiga fraksi dari sembilan eluen hasil kromatografi kolom dengan kode etil asetat 1 , etil asetat 2 dan etil asetat 3 . Hasil pengujian menunjukkan fraksi etil asetat 1 memiliki aktivitas antimitotik terkuat dari kedua fraksi lainnya. Fraksi etil asetat 1 masih menunjukkan efek pengeritingan pada konsentrasi $0,7 \mu \mathrm{g} / \mathrm{ml}$. Fraksi etil asetat 2 juga menunjukkan efek pengeritingan pada miselia jamur uji sampai pada konsentrasi $6,2 \mu \mathrm{g} / \mathrm{ml}$. Fraksi etil asetat 3 memperlihatkan efek pengeritingan yang lemah, yakni hanya sampai konsentrasi $12,5 \mu \mathrm{g} / \mathrm{ml}$ dan pada konsentrasi di bawah $12,5 \mu \mathrm{g} / \mathrm{ml}$ menunjukkan pertumbuhan normal miselia jamur uji (tidak tampak efek pengeritingan). Hasil pengujian dapat dilihat ada Gambar 5.

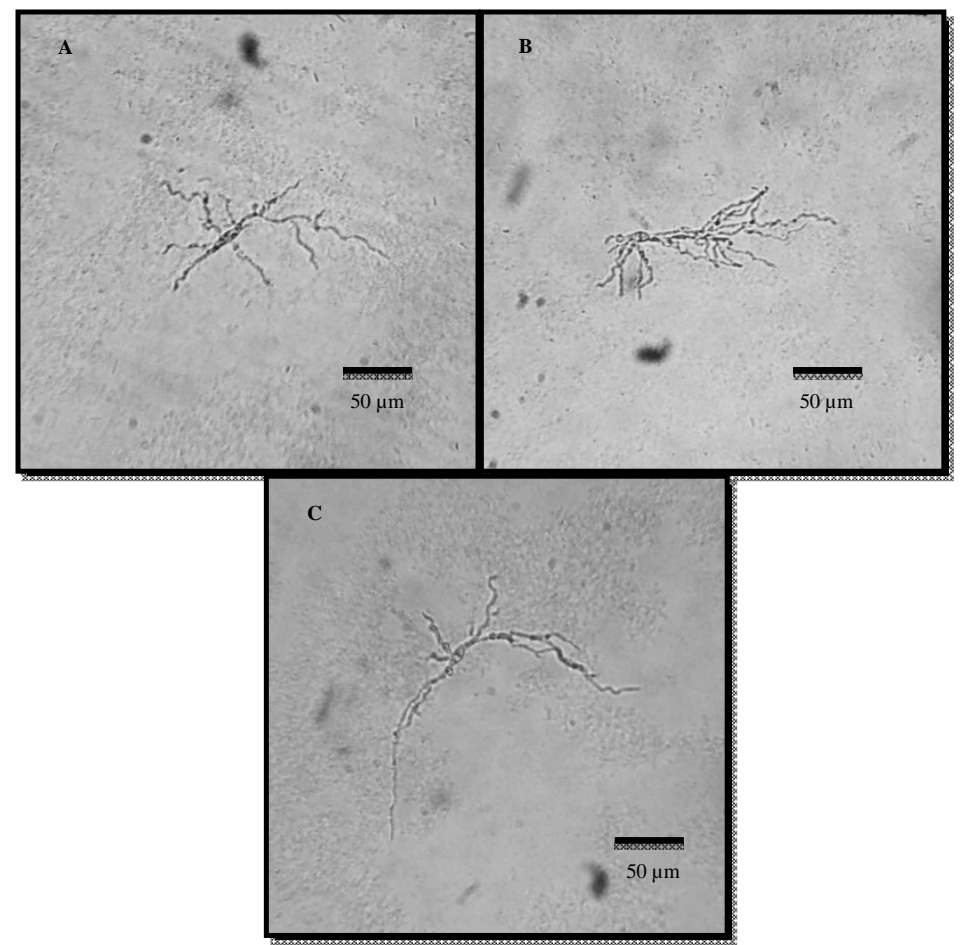

Keterangan : A.Etil Asetat $10,7 \mu \mathrm{g} / \mathrm{ml}$, B.Etil Asetat $26,2 \mu \mathrm{g} / \mathrm{ml}$, C.Etil Asetat $312,5 \mu \mathrm{g} / \mathrm{ml}$

Gambar 5. Efek Pengeritingan oleh Fraksi Hasil Kromatografi Kolom Sinularia 3 
Karang lunak genus Sinularia merupakan sumber senyawa potensial. Ahmed et al (2003) berhasil mengisolasi senyawa $\beta$-caryophyllene turunan terpenoid dari $S$. nanolobata. Ahmed et al (2004) mengisolasi senyawa scabrolides $E$ - G dari S. scabra dan senyawa norcembranoid dari $S$. leptoclados dan $S$. parva. Ahmed et al (2005) mendapatkan senyawa terpenoid oxigenasi dari $S$. gibbernosa. Cheng et al (2009) mendapatkan senyawa terpenoid capillosanol dari $S$. capillosa. Lu et al (2010) mendapatkan dua cembranoid bernama senyawa granosolides dari S. granosa dan senyawa querciformolide $E$ dari $S$. querciformis. Senyawa Furanosesquiterpene diisolasi dari karang lunak $S$. kavarittiensis yang dapat menghambat pertumbuhan sel leukemia (Arepalli, 2007). Karang lunak genus Sinularia dapat dijadikan salah satu sumber potensial dalam penemuan senyawa antimitotik yang baru.

Menurut Richmond (1975), morfologi jamur dapat berubah akibat penggunaan bahan beracun. Leslie, et al (2010) menyatakan mikrotubulus mempunyai peranan penting dalam pencarian agen antimitotik. Senyawa antimitotik mengubah keseimbangan tubulin dan menyebabkan penghambatan mitosis sehingga terjadi kematian sel secara apoptosis. Gangguan pada gelendong mitosis mendorong penghambatan berkepanjangan dari pembelahan mitosis yang akhirnya menyebabkan kematian sel (Reider dan Maiato, 2004). Berdasarkan keseluruhan hasil penelitian maka, efek pengeritingan dari miselia jamur $P$. oryzae merupakan respons dari penghentian pembelahan mitosis akibat dari pemberian senyawa metabolit. Penghentian mitosis sel terjadi karena pembentukan mikrotubulus sel terganggu.

\section{KESIMPULAN}

Setelah dilakukan serangkaian pengujian aktivitas, maka dapat ditarik kesimpulan bahwa dari keempat jenis karang lunak genus Sinularia yang digunakan pada penelitian ini, karang lunak Sinularia 3 menunjukkan aktivitas antimitotik terkuat. Dari hasil penelitian dapat disarankan perlu dilakukan penentuan rumus struktur dan penentuan cara kerja senyawa antimitotik dari fraksi etil asetat 1 Sinularia 3 hasil kromatografi kolom yang merupakan fraksi unggul, serta pengujian lebih lanjut secara in vitro dan in vivo terhadap sel kanker.

\section{UCAPAN TERIMA KASIH}

Terima kasih kepada Elvina Rumabarar, S.Kel. yang telah melakukan pengambilan sampel dan menyediakan ekstrak yang telah dipartisi untuk digunakan pada penelitian ini. Diucapkan juga terima kasih kepada Prof. M. Namikoshi dari Tohoku Pharmaceutical University Jepang yang telah memberikan kesempatan untuk menggunakan KCKT.

\section{DAFTAR PUSTAKA}

Ahmed, A. F; Ru-Ting Shiue; Guey-Horng Wang; Chang-Feng Dai; Yao-Haur Kuo and Jyh-Horng Sheu. 2003. Five Novel norcembranoids from Sinularia leptoclados and S. parva. Tetrahedron Letters 59, 7337-7344.

Ahmed, A. F; Jui-Hsin Su; Ru-Ting Shiue; XinJie Pan; Chang-Feng Dai; Yao-Haur Kuo and Jyh-Horng Sheu. 2004. New $\beta$ Caryophyllene-Drived Terpenoids from the Soft Coral Sinularia nanolobata. Journal of Natural Products 67, 592-597.

Ahmed, A. F; Jui-Hsin Su; Yao-Haur Kuo and Jyh-Horng Sheu. 2004. Scabrolides E $G$ Three New Norditrpenoids from the Soft Coral Sinularia scabra. Journal of Natural Products 67, 2079-2082.

Ahmed, A. F; Yao-Haur Kuo; Chang-Feng Dai and Jyh-Horng Sheu. 2005.

Oxgenated Terpenoids from a Formosan Soft Coral Sinularia gibbernosa. Journal of Natural Products 68, 1208-1212.

Andersen, R.J; M.Roberge and B.Cinel. 2004. Antimitotic Compounds. http://www.freepatentsonline.com/681203 7.html. 12 Desember 2014.

Arepalli, S. K; V. Sridhar; J. Venkateswara Rao; P. Kavin Kennady and Y. Venkateswarlu. 2007. Furanosesquiterpene from soft coral, Sinularia kavarittiensis: induces apoptosis via the mitochondrial-mediated caspasedependent pathway in THP-1, leukemia cell line. Journal of Medicine 14(5), 729740.

Cheng, Shi-Yie; Ki-Jhih Huang; Shang-Kwei Wang; Zhi-Horng Wen Chi-Hsin Hsu; Chang-Feng Dai and Chang-Yih Duh. 2009. New Terpenoids from the Soft Corals Sinularia capillosa and Nephthea chabroli. http://pubs.acs.org. doi: 10.1021/ol901864. 2 Oktober 2014.

Chrousos, G; P. Zoumakis, Emmanouil and A. Gravanis. 2001. In Bertram G. Katzung (Ed.), Basic and Clinical Pharmacology 
(8th edition). New York: Lange Medical Books/McGraw-Hill. pp:704-707.

Gascoigne, K.E and S.S Taylor. 2009. How do anti-mitotics drugs kill cancer cells?. Journal of Cell Science 122, 2579-2585.

Kobayashi, H; M. Namikoshi; T. Yoshimoto and T. Yokochi. 1996. A Screening Method For Antimitotic and Antifungal substances Using Conidia of Pyricularia oryzae, Modification and Application to Tropical Marine Fungi. The Journal of Antibiotics. 49(9), 873-879.

Leslie, B.J; C.R Holaday; T. Nguyen and P.J Hergenrother. 2010. Phenylcinnamides as Novel Antimitotic Agents. Journal of Medicinal Chemistry 53, 3964-3972.

Lu, Yi; Jui-Hsin SU; Chiung-Yao Huang; YungChun Liu; Yao-Haur Kuo; Zhi-Hong Wen; Chi-Hsin Hsu and Jyh-Horng Sheu. 2010. Cembranoids from the Soft Corals Sinularia granosa and Sinularia querciformis. Chemical and Pharmaceutical Bulletin 58(4), 464-466.

Richmond, D.V. 1975. Effects of toxicants on the morphology and fine structure of fungi. Advances in Applied Microbioogyl 19, 289-319.

Rieder, C. L. and H. Maiato. 2004. Stuck in division or passing through: what happens when cells cannot satisfy the spindle assembly checkpoint. Dev Cell 7, 637-651.

Rumbarar, E. 2008. Skrining Aktivitas Antimitotik dari Beberapa Fraksi Ekstrak Karang Lunak Asal Perairan Pantai Malalayang Manado. SKRIPSI FPIK UNSRAT. Manado.

Sullivan, A.S; V. Prasad; M.C. Roach; M. Takahashi; S. Iwasaki and R.F. Ludueña. 1990. Interaction Rhizoxin of Bovine Brain Tubulin. Cancer Research 50, 4277-4280. 